\title{
ERRATUM
}

\section{Largonji des Loucherbems: An Optimality-Theoretic analysis of a 19th century French Language Game- ERRATUM}

\section{AVERY OZBURN AND MURRAY SCHELLENBERG}

https://doi.org/10.1017/cnj.2018.46. Published by Cambridge University Press, 21 December 2018

There was an error in the title of the article by Ozburn and Schellenberg (2019) in the September 2019 issue of Canadian Journal of Linguistics. This has been corrected online.

\section{REFERENCE}

Ozburn, Avery, and Murray Schellenberg. 2019. Largonji des Loucherbems: An OptimalityTheoretic analysis of a 19th century French Language Game, Canadian Journal of Linguistics 64(3): 509-37. https://doi.org/10.1017/cnj.2018.46. 